\title{
PERAN PROFESI NOTARIS \\ DALAM MENJAGA KEWIBAWAAN NEGARA HUKUM INDONESIA
}

\author{
Mirin Primudyastutie \\ Fakultas Hukum Universitas Islam Malang \\ Email: mirinprimudyastutie@unisma.ac.id \\ Anang Sulistyono \\ Fakultas Hukum Universitas Islam Malang \\ Email: anangsulistyono@unisma.ac.id
}

\begin{abstract}
Abstrak
Eksistensi norma yuridis merupakan norma yang mengatur tentang peran yang bisa dilakukan oleh subyek hukum atau pihak yang ditunjukknya, diantaranya notaris. Norma yuridis yang menjadi pijakan utama bagi notaris diantaranya untuk menjalankan kewajiban-kewajiban atau kewenangan-kewenangannya. Peran mengimplementasikan norma yuridis ini adalah berkaitan dengan tugas, kewajiban, kewenangan, larangan, dan lain sebagainya yang menentukan terhadap bekerjanya hukum, sehingga yang dilakukannya ini mengandung konsekuensi yuridis, yakni kewibawaan negara hukum. Ada hak-hak masyarakat dan martabat negara yang ikut dirugikan ketika norma hukum tidak dijalankan sebagaimana yang sudah digariskannya. Kewibawaan negara hukum merupakan ujian riil propfesionalitas sebagai notaris, sehingga Ketika peran yang ditunjukkan tidak profesionalitas, dampak seriusnya terhadap kewibawaan negara hukum.
\end{abstract}

Kata Kunci: kewibawaan, notaris, peran, negara

\section{Abstract}

The existence of juridical norms is a norm that regulates the roles that can be performed by a legal subject or party appointed by it, including a notary. Juridical norms that become the main foothold for notaries include to carry out their obligations or authorities. The role of implementing this juridical norm is related to the duties, obligations, authorities, prohibitions, etc. that determine the operation of the law, so that what it does has juridical consequences, namely the authority of the rule of law. There are community rights and state dignity that are also harmed when legal norms are not implemented as outlined by them. The authority of a rule of law is a real test of professionalism as a notary, so that when the 
role shown is not professional, it has a serious impact on the authority of the rule of law.

Keywords: authority, notary, role, state

\section{PENDAHULUAN}

Undang-Undang Republik Indonesia Nomor 2 Tahun 2014 Tentang Perubahan Atas Undang-Undang Nomor 30 Tahun 2004 Tentang Jabatan Notaris merupakan produk legislalatif yang menunjukkan, bahwa pembaruan hukum yang dilakukan oleh negara, khususnya yang mengatur notaris adalah berkaitan dengan kepentingan pemenuhan hak-hak masyarakat dan dunia hukum. Norma hukum demikian dibutuhkan untuk mengatur hubungan kehidupan bermasyarakat dan bernegara. Dalam hubungan yang dibangun oleh setiap orang atau pihak, ditentukan oleh norma yang mengaturnya. Norma yang mengatur ini menjadi pijakan kepastian bersikap dan berperilakunya.

Dalam Penjelasan Undang-Undang Republik Indonesia Nomor 2 Tahun 2014 Tentang Perubahan Atas Undang-Undang Nomor 30 Tahun 2004 Tentang Jabatan Notaris disebutkan, bahwa Negara Republik Indonesia sebagai negara hukum berdasarkan Pancasila dan UndangUndang Dasar Negara Republik Indonesia Tahun 1945 menjamin kepastian, ketertiban, dan perlindungan hukum bagi setiap warga negara. Untuk menjamin kepastian, ketertiban, dan perlindungan hukum dibutuhkan alat bukti tertulis yang bersifat autentik mengenai perbuatan, perjanjian, penetapan, dan peristiwa hukum yang dibuat di hadapan atau oleh Notaris. Notaris sebagai pejabat umum yang menjalankan profesi dalam memberikan jasa hukum kepada masyarakat, perlu mendapatkan perlindungan dan jaminan demi tercapainya kepastian hukum. Jaminan perlindungan dan jaminan tercapainya kepastian hukum terhadap pelaksanaan tugas Notaris telah diatur dalam Undang-Undang Nomor 30 Tahun 2004 tentang Jabatan Notaris. Namun, beberapa ketentuan dalam Undang-Undang tersebut sudah tidak sesuai lagi dengan perkembangan hukum dan kebutuhan masyarakat sehingga perlu dilakukan perubahan, yang juga dimaksudkan untuk lebih menegaskan dan memantapkan tugas, fungsi, dan kewenangan Notaris sebagai pejabat yang menjalankan pelayanan publik, sekaligus sinkronisasi dengan undang-undang lain.

Idealisme hukum adalah mengatur pergaulan hidup secara damai. ${ }^{1}$ Dalam setiap kehidupan manusia sebagai mahluk sosial akan selalu berinteraksi dengan manusia yang lain. Dengan adanya interaksi ini akan timbul kepentingan perseorangan dan kepentingan golongan yang kadang

${ }^{1}$ L.J. Van Apeldoorn, Pengantar Ilmu Hukum, Jakarta: Djambatan, 1986, hlm. 
menimbulkan pertikaian, akan tetapi dengan interaksi juga memberikan manfaat dengan menambah pengetahuan serta informasi lainnya.

Menurut Satjipto Rahardjo, ${ }^{2}$ bahwa norma hukum adalah sarana yang dipakai oleh masyarakat untuk mengarahkan tingkah laku anggota masyaakat pada saat mereka berhubungan antara yang satu dengan lainnya. Apabila di sini disinggung tentang "mengarahkan tingkah laku", barang tentu pertanyaan dalam diri kita, "mengarahkan kemana"? ke mana norma itu mengarahkan tingkah laku manusia merupakan prioritas yang ada pada masyarakat sendiri. Masyarakatlah yang menentukan arah-arah tersebut dan oleh karena itu kita bisa melihat norma itu sebagai pencerminan dari kehendak masyarakat. Kehendak masyarakat untuk mengarahkan tingkah laku anggota-anggota masyarakat itu dilakukan dengan membuat pilihan antara tingkah laku yang disetujui dan yang tidak disetjui yang kemudian merupakan norma dalam masyarakat itu. Oleh karena itu, norma hukum itu merupakan persyaratan dari penilaian-penilaian

Pertimbangan tersebut juga dapat dibaca dalam dasar pertimbangan Undang-Undang Republik Indonesia Nomor 2 Tahun 2014 Tentang Perubahan Atas Undang-Undang Nomor 30 Tahun 2004 Tentang Jabatan Notaris, bahwa a. Negara Republik Indonesia sebagai negara hukum berdasarkan Pancasila dan Undang-Undang Dasar Negara Republik Indonesia Tahun 1945 menjamin kepastian, ketertiban, dan perlindungan hukum bagi setiap warga negara; b. bahwa untuk menjamin kepastian, ketertiban, dan perlindungan hukum dibutuhkan alat bukti tertulis yang bersifat autentik mengenai perbuatan, perjanjian, penetapan, dan peristiwa hukum yang dibuat di hadapan atau oleh pejabat yang berwenang; c. bahwa Notaris sebagai pejabat umum yang menjalankan profesi dalam memberikan jasa hukum kepada masyarakat, perlu mendapatkan perlindungan dan jaminan demi tercapainya kepastian hukum.

\section{METODE PENELITIAN}

Dalam penelitian ini, penulis menggunakan jenis penelitian bersifat deskriptif. Suatu penelitian deskriptif ini dimaksudkan untuk memberikan data yang seteliti mungkin tentang manusia, keadaan atau gejala-gejala lainya. ${ }^{3}$ Penelitian hukum ini juga menggunakan pendekatan yuridis normatif. Penelitian hukum dengan pendekatan yuridis normatif ini dilakukan dengan cara meneliti bahan pustaka atau data sekunder. Penelitian

2 Al-Hilal Hamdi, Menjelajah Dunia Hukum, Jakarta: LPP-Mpres, 2017, hlm. 2.

${ }^{3}$ Soerjono Soekanto, Pengantar Penelitian Hukum, Jakarta: Sinar Grafika, 1986, hlm. 9. 
hukum ini dapat juga dinamakan penelitian hukum kepustakaan. ${ }^{4}$ Penelitian hukum dengan yang menggunakan pendekatan yuridis normatif dilakukan dengan menggunakan bahan yang diperoleh dari studi pustaka. Berdasarkan dengan hal ini maka dalam menganalisis data yang diperoleh, penulis menggunakan metode atau teknik analisis isi (content analysis), yaitu suatu analisis terhadap isi data yang diperoleh.

\section{PEMBAHASAN}

\section{Profesi Notaris Sebagai Profesi Strategis}

Kata notaris berasal dari kata "nota literaria" yaitu tanda tulisan atau karakter yang dipergunakan untuk menuliskan atau menggambarkan ungkapan kalimat yang disampaikan nara sumber. Tanda atau karakter yang dimaksud adalah tanda yang dipakai dalam penulisan cepat (stenografie). ${ }^{5}$

Pada awalnya jabatan notaris hakikatnya adalah sebagai pejabat umum (private notary) yang ditugaskan oleh kekuasaan umum untuk melayani kebutuhan masyarakat akan alat bukti otentik yang memberikan kepastian hubungan hukum keperdataan. Jadi, sepanjang alat bukti otentik tetap diperlukan oleh sistem hukum negara maka jabatan notaris akan tetap diperlukan eksistensinya di tengah masyarakat.

Notaris seperti yang dikenal di zaman "Republik der Verenigde Nederlanden" mulai masuk di Indonesia pada permulaan abad ke-17 dengan beradanya "Oost Ind. Compagnie" di Indonesia. ${ }^{6}$

Pada tanggal 27 Agustus 1620, yaitu beberapa bulan setelah dijadikannya Jacatra sebagai ibukota (tanggal 4 Maret 1621 dinamakan "Batavia"), Melchior Kerchem, Sekretaris dari "College van Schepenen" di Jacatra, diangkat sebagai notaris pertama di Indonesia. Di dalam akta pengangkatan Melchior Kerchem sebagai notaris sekaligus secara singkat dimuat suatu instruksi yang menguraikan bidang pekerjaan dan wewenangnya, yakni untuk menjalankan tugas jabatannya di kota Jacatra untuk kepentingan publik. Kepadanya ditugaskan untuk menjalankan pekerjaannya itu sesuai dengan sumpah setia yang diucapkannya pada waktu pengangkatannya di hadapan Baljuw di Kasteel Batavia.

Notaris adalah pejabat umum yang satu-satunya berwenang untuk membuat akta otentik mengenai semua perbuatan, perjanjian dan penetapan yang diharuskan oleh suatu peraturan umum atau oleh yang berkepentingan

\footnotetext{
${ }^{4}$ Soerjono Soekanto \& Sri Mamudji, Penelitian Hukum Normatf, Jakarta: Rajagrafindo Persada, 2003, hlm. 13-14.

${ }^{5}$ G.H.S. Lumban Tobing, Peraturan Jabatan Notaris (Notaris Reglement), Jakarta: Erlangga, 1980, hlm. 41

${ }^{6}$ G.H.S. Lumban Tobing, Peraturan Jabatan Notaris, cet. 3, Jakarta: Erlangga, 1983, hlm. 15
} 
dikehendaki untuk dinyatakan dalam suatu akta otentik, menjamin kepastian tanggalnya, menyimpan aktanya dan memberikan grosse, salinan dan kutipannya, semuanya sepanjang pembuatan akta itu oleh suatu peraturan umum tidak juga ditugaskan atau dikecualikan kepada pejabat atau orang lain. ${ }^{7}$

Menurut Peraturan Menteri Hukum dan Hak Asasi Manusia RI No. M.01-HT.03.01 Tahun 2006, tentang Syarat dan Tata Cara Pengangkatan dan Pemindahan, dan Pemberhentian Notaris, dalam Pasal 1 ayat (1), yang dimaksud dengan Notaris adalah pejabat umum yang berwenang untuk membuat akta otentik dan kewenangan lainnya, sebagaimana dimaksud dalam Undang-Undang Jabatan Notaris.

Notaris adalah pejabat umum maksudnya adalah seseorang yang diangkat, diberi wewenang dan kewajiban oleh Negara untuk melayani publik dalam hal tertentu.

Notaris merupakan pejabat publik yang menjalankan profesi dalam pelayanan hukum kepada masyarakat, guna memberi perlindungan dan jaminan hukum demi tercapainya kepastian hukum dalam masyarakat. Pejabat umum adalah orang yang menjalankan sebagian fungsi publik negara, yang khususnya di bidang hukum perdata. Bahwa untuk membuat akta otentik, seseorang harus mempunyai kedudukan sebagai "pejabat umum".

Berdasarkan pengertian-pengertian Notaris diatas ada hal penting yang tersirat, yaitu ketentuan dalam permulaan pasal tersebut, bahwa Notaris adalah pejabat umum dimana kewenangannya atau kewajibannya yang utama ialah membuat akta-akta otentik, jadi Notaris merupakan pejabat umum sebagaimana yang dimaksud pada Pasal 1868 KUHPerdata.

Pengertian Notaris Menurut pengertian Undang-Undang No. 30 Tahun 2004 tentang Jabatan Notaris (sudah diubah dengan Undang-undang baru) dalam Pasal 1 disebutkan pengertian Notaris adalah pejabat umum yang berwenang untuk membuat akta otentik dan kewenangan lainnya sebagaimana dimaksud dalam Undang-Undang ini.

Syarat untuk dapat diangkat menjadi Notaris sebagaimana diatur dalam Pasal 3 Undang-Undang No. 30 Tahun 2004 tentang Jabatan Notaris (sudah diubah dengan Undang-undang baru) adalah:

1. Warga negara Indonesia;

2. Bertakwa kepada Tuhan Yang Maha Esa;

3. Berumur paling sedikit 27 tahun;

4. Sehat jasmani dan rohani;

5. Berijazah sarjana hukum dan lulusan jenjang strata dua kenotariatan; 
6. Telah menjalani magang atau nyata-nyata telah bekerja sebagai karyawan Notaris dalam waktu 12 bulan berturut-turut pada kantor Notaris atas prakarsa sendiri atau atas rekomendasi Organisasi Notaris setelah lulus strata dua kenotariatan; dan

7. Tidak berstatus sebagai pegawai negeri, pejabat negara, advokat, atau tidak sedang memangku jabatan lain yang oleh UndangUndang dilarang untuk dirangkap dengan jabatan Notaris.

Dari sisi sejarah, semula dikenal pejabat umum. Istilah pejabat umum merupakan terjemahan dari istilah Openbare Ambteneran yang terdapat dalam pasal 1868 KUHPerdata. Pasal 1868 KUHPerdata menyebutkan: "Eene authentieke acte is de zoodanige welke in de wettelijken vorn is verleden, door of ten overstaan van openbare ambtenaren die daartoe bevoegd zijn ter plaatse alwaar zuiks is geschied." (Suatu akta otentik ialah suatu akta yang dibuat dalam bentuk yang ditentukan undang-undang oleh atau di hadapan pejabat umum yang berwenang untuk itu di tempat akta itu dibuat).

Openbare Ambtenaren yang diterjemahkan sebagai Pejabat Umum diartikan sebagai pejabat yang diserahi tugas untuk membuat akta otentik yang melayani kepentingan publik, dan kualifikasi seperti itu diberikan kepada Notaris. Maka berdasarkan ketentuan Pasal 1868 Kitab UndangUndang Hukum Perdata tersebut, untuk dapat membuat suatu akta otentik seseorang harus mempunyai kedudukan sebagai pejabat umum. Namun dalam Pasal 1868 itu tidak menjelaskan lebih lanjut mengenai siapa yang dimaksud sebagai pejabat umum tersebut.

Menurut kamus hukum salah satu arti dari Ambtenaren adalah Pejabat. Dengan demikian Openbare Ambtenaren adalah pejabat yang mempunyai tugas yang bertalian dengan kepentingan publik, sehingga tepat jika Openbare Ambtenaren diartikan sebagai Pejabat Publik. Khusus berkaitan dengan Openbare Ambtenaren yang diterjemahkan sebagai Pejabat Umum diartikan sebagai pejabat yang diserahi tugas untuk membuat akta otentik yang melayani kepentingan publik, dan kualifikasi seperti itu diberikan kepada Notaris.

Menurut pengertian Undang Undang No. 30 tahun 2004 dalam pasal 1 disebutkan definisi notaris, yaitu: "Notaris adalah pejabat umum yang berwenang untuk membuat akta otentik dan kewenangan lainnya sebagaimana maksud dalam undang-undang ini."

Pejabat umum adalah orang yang menjalankan sebagian fungsi publik dari negara, khususnya di bidang hukum perdata. Pejabat umum adalah seseorang yang diangkat dan diberhentikan oleh pemerintah dan diberi wewenang dan kewajiban untuk melayani publik dalam hal-hal tertentu karena ia ikut serta melaksanakan suatu kekuasaan yang bersumber 
pada kewibawaan dari pemerintah. Dalam jabatannya tersimpul suatu sifat atau ciri khas yang membedakannya dan jabatan-jabatan lainnya dalam masyarakat.

Sebagai pejabat umum, Notaris diangkat oleh Menteri untuk melaksanakan sebagian fungsi publik dari negara dan bekerja untuk pelayanan kepentingan umum khususnya dalam bidang hukum perdata, walaupun Notaris bukan merupakan pegawai negeri yang menerima gaji dari Negara. Pelayanan kepentingan umum tersebut adalah dalam arti bidang pelayanan pembuatan akta dan tugas-tugas lain yang dibebankan kepada Notaris, yang melekat pada predikat sebagai pejabat umum dalam ruang lingkup tugas dan kewenangan Notaris.

Akta Notaris yang diterbitkan oleh notaris memberikan kepastian hukum bagi masyarakat. Menurut Nusyirwan Notaris adalah orang semi swasta, karena ia tidak bisa bertindak bebas sebagaimana seorang swasta. Ia harus menjunjung tinggi martabatnya, oleh karena itu ia diperkenankan menerima uang jasa (honorarium) untuk setiap pelayanan yang diberikannya. ${ }^{8}$

"Honorarium" berasal dan kata latin Honor yang artinya kehormatan, kemuliaan, tanda hormat/ penghargaan semula mengandung pengertian balas jasa para nasabah atau klien kepada dokter, akuntan, pengacara, dan Notaris. ${ }^{9}$

Di Indonesia para notaris berhimpun dalam sebuah wadah perkumpulan yang bernama I.N.I. I.N.I merupakan perkumpulan notaris yang legal dan sudah berbadan hukum sesuai dengan SK Menteri Kehakiman Republik Indonesia Tanggal 23 Januari 1995 Nomor C210221.HT.01.06. Sebagai organisasi perkumpulan notaris, INI menaungi kegiatan praktik notaris-notaris di Indonesia.

Secara umum, terdapat dua aliran dalam praktik kenotariatan, Notaris Latin yang mengadopsi Civil law System dan Notaris Anglo Saxon mengadopsi Sistem Hukum Khusus Common law System sehingga tidak bisa dicampuradukkan. Perbedaan antar aliran itu terletak pada fungsi yang dijalankan masing-masing notaris. Notaris Latin adalah satusatunya pejabat negara yang berhak mengeluarkan akta otentik. Sedangkan Notaris Anglo Saxon adalah notaris yang hanya mengeluarkan akta di bawah tangan yang tidak bernilai di pengadilan.

Sementara menurut Izenic, sebagaimana dikutip oleh Komar Andasasmita dan dikutip kembali oleh Habib Adjie, bentuk atau corak notaris dapat dibagi menjadi dua kelompok utama, yaitu:

\footnotetext{
${ }^{8}$ Nusyirwan, Membedah Profesi Notaris, Bandung: Universitas Padjadjaran, 2000, hlm, 3-4

${ }^{9}$ Ensiklopedi Nasional Indonesia, Jakarta: Delta Pamungkas, 2004, hlm, 472,
} 
1. Notariat Functionnel Dalam mana wewenang-wewenang pemerintah didelegasikan (gedelegeerd) dan demikian diduga mempunyai kebenaran isinya, mempunyai kekuatan bukti formal, dan mempunyai daya/ kekuatan eksekusi. Di negara-negara yang menganut macam/ bentuk notariat seperti ini terdapat pemisahan yang keras antara "wettelijke" dan "niet wettelijke" werkzaamheden, yaitu pekerjaan-pekerjaan yang berdasarkan undang-undang/ hukum dan yang tidak/ bukan dalam notariat,

2. Notariat Professional Dalam kelompok ini walaupun pemerintah mengatur tentang organisasinya, akta-akta notaris itu tidak mempunyai akibat-akibat khusus tentang kebenarannya, kekuatan bukti, demikian pula kekuatan eksekutorialnya. Konsep pengembangan undang-undang dan peraturan kenotariatan di sebuah negara harus mengacu pada konsep besar mazab kenotariatan ini karena masing-masing memiliki landasan filosofi hukum yang berbeda. ${ }^{10}$

\section{Menjaga Kewibawaan Negara Hukum}

Mochtar Kusumaatmadja menyebut bahwa pemahaman hukum yang memadai harus tidak hanya memandang hukum itu sebagai suatu perangkat kaidah dan asas-asas yang mengatur kehidupan manusia dalam masyarakat, tapi harus pula mencakup lembaga (institusi) dan proses yang diperlukan untuk mewujudkan hukum itu dalam kenyataan. ${ }^{11}$

Negara membuat norma yuridis untuk kepentingan pergaulan manusia dalam hubungannya dengan manusia lain. Meski demikian, ada beberapa pendapat mengenai hukum yang antara sarjana satu dengan lainnya tidak sama. Tiap manusia mempunyai sifat, watak, dan kehendak sendiri-sendiri. Namun di dalam masyarakat manusia mengadakan hubungan antara yang satu dengan lainnya, mengadakan kerjasama, tolong menolong, Bantu membantu, dan lainnya untuk memperoleh keperluan hidupnya. Keperluan atau kepentingan manusia kadang-kadang baru bisa dipenuhi oleh manusia lainnya Peran manusia lain akan menjadikan terjadinya hubungan sosial yang lebih baik dan saling menguntungkan. ${ }^{12}$ Negara yang dimaksudkan disini adalah negara hukum atau negara yang menggunakan hukum sebagai instrumen dalam mengatur dirinya.

${ }^{10}$ Habib Adjie, Meneropong Khazanah Notaris \& PPAT Indonesia (kumpulan tulisan tentang Notaris dan PPAT), Bandung: Citra ADitya Bakti, 2009, hlm. 1-2

${ }^{11}$ DPD-Unibraw, Konstruksi Perwakilan Daerah Dalam Sistem Ketatanegaraan Indonesia, Kerjasama DPD RI dan Universitas Brawijaya, Malang: Pusat Pengkajian Konstitusi Fakultas Hukum Universitas Brawijaya, 2009, hlm. 15.

12 CST. Kansil, Pengantar Hukum dan Tata Hukum Indonesia, Jakarta: Djambatan, 2000, hlm. 33. 
PERAN PROFESI NOTARIS DALAM MENJAGA KEWIBAWAAN NEGARA HUKUM INDONESIA (Mirin Primudyastutie, Anang Sulistyono)

Istilah "rechtsstaat" (negara hukum) adalah suatu istilah muncul abad ke-19. Lebih muda dari dari istilah-istilah ketatanegaraan lainnya seperti: demokrasi, konstitusi, kedaulatan, dan lain sebagainya. Menurut Soediman Kartohadiprodjo, istilah "rechtsstaat" pertama kali digunakan oleh Rudolf ven Gueist seorang guru besar Berlin. Tetapi konsep negara hukum itu sendiri sudah dicetuskan sejak abad ke-17, bersama-sama dengan timbulnya perlawanan terhadap sistem pemerintahan (kekuasaan) yang absolut, otoriter, bahkan sewenang-wenang. Secara teoritikal konsep negara hukum lahir sebagai reaksi terhadap konsep kedaulatan negara tradisional yang di gagas oleh: Augustinus, Thomas Aquinas (teori kedaulatan tuhan), Machiavelli, Paul Laband, Georg Jellinek (teori negara kekuasaan), Jean Bodin (teori kedaulatan raja), Thomas Hobbes (teori konstruk, Home homini lupus), Rouseau, Montesquieu, John Lockc (teori kedaulatan rakyat), Hugo de Groot, Krabbe, Leon Duguit (teori kedaulatan hukum atau supremacy of law). ${ }^{13}$

Joeniarto menyatakan bahwa negara hukum "asas the rule of law" berarti bahwa dalam penyelenggaraan Negara, segala tindakan penguasa dan aktifitas masyarakat negara harus berdasarkan atas hukum dan bukan berdasarkan atas kekuasaan belaka dengan maksud untuk membatasi kekuasaan penguasa dan melindungi kepentingan masyarakat yakni ${ }^{13}$ C.S.T. Kansil, Christine S.T. Kansil, dalam Al-Hilal Hamdi, Op.Cit, hlm. 23, 
perlindungan terhadap hak asasi manusia dari tindakan yang sewenangwenang.

Mustofa Kamal Pasha menyebut, bahwa negara hukum secara sederhana adalah negara yang penyelenggaraan kekuasaan pemerintahannya didasarkan atas hukum. Dalam negara hukum, kekuasaan menjalankan pemerintahan berdasarkan kedaulatan hukum (supremasi hukum) dan bertujuan untuk menjalankan ketertiban hukum. Ada pendapat lain yang menyebutkan bahwa dalam negara hukum, hukum sebagai dasar diwujudkan dalam peraturan perundang-undangan yang berpuncak pada konstitusi atau hukum dasar negara. Konstitusi negara juga harus berisi gagasan atau ide tentang konstitusionalisme, yaitu adanya pembatasan atas kekuasaan dan jaminan hak dasar warga negara. Dengan demikian dalam negara hukum, kekuasaan negara berdasar atas hukum, bukan kekuasaan belaka serta pemerintahan negara berdasar pada konstitusi yang berpaham konstitusionalisme, tanpa hal tersebut sulit disebut sebagai negara hukum. Supremasi hukum harus mencakup tiga ide dasar hukum, yakni keadilan, kemanfaatan, dan kepastian. Oleh karena itu di negara hukum, hukum harus tidak boleh mengabaikan "rasa keadilan masyarakat". Negara-negara komunis atau negara otoriter memiliki konstitusi tetapi menolak gagasan 
PERAN PROFESI NOTARIS DALAM MENJAGA KEWIBAWAAN NEGARA HUKUM INDONESIA (Mirin Primudyastutie, Anang Sulistyono)

tentang konstitusionalisme sehingga tidak dapat dikatakan sebagai negara hukum dalam arti sesungguhnya. ${ }^{14}$

Jimly Asshiddiqie menyatakan bahwa negara hukum adalah unik, sebab negara hendak dipahami sebagai suatu konsep hukum. Dikatakan sebagai konsep yang unik karena tidak ada konsep lain. Dalam negara hukum nantinya akan terdapat satu kesatuan sistem hukum yang berpuncak pada konstitusi atau undang-undang dasar. Dengan adanya hal tersebut, penyelenggaraan negara dan rakyat dapat bersatu di bawah dan tunduk pada sistem yang berlaku. Sehingga konstitusi negara merupakan sarana pemersatu bangsa. Dalam perkembangannya, negara hukum yang pertama terbentuk adalah negara hukum formil, yang merupakan negara hukum dalam arti sempit yaitu negara hukum yang membatasi ruang geraknya dan bersifat pasif terhadap kepentingan rakyat negara. Negara tidak campur tangan secara banyak terhadap urusan dan kepentingan warga negara. Namun seiring perkembangan zaman, negara hukum formil berkembang menjadi negara hukum materiil yang berarti negara yang pemerintahannya memiliki keleluasaan untuk turut campur tangan dalam urusan warga dengan dasar bahwa pemerintah ikut bertanggung jawab terhadap

14 http://prince-mienu.blogspot.com/2010/01/negara-hukum.html, akses 2 Juni 2020. 
kesejahteraan rakyat. Negara bersifat aktif dan mandiri dalam upaya membangun kesejahteraan rakyat. ${ }^{15}$

Menurut Hugo Krabbe (guru besar Universitas Leiden), yang dimaksud dengan "hukum" pada konsep negara hukum bukan semata-mata hukum formal yang diundangkan, tetapi hukum yang ada di masyarakat, dan hukum formal adalah benar apabila sesuai dengan hukum materil yakni perasaan hukum yang hidup di masyarakat.

Menurut Friedrich Julius Stahl, negara hukum harus memenuhi (memiliki) empat unsur (elemen) yaitu: (1) terjaminnya Hak Asasi Manusia (HAM), (2) pembagian kekuasaan, (3) pemerintahan berdasarkan peraturan perundang-undangan, dan (4) peradilan tata usaha negara. ${ }^{16}$

Frans Magnis Suseno mengemukakan adanya 5 (lima) ciri negara hukum sebagai salah satu ciri hakiki negara demokrasi. Kelima ciri negara hukum tersebut adalah sebagai berikut.

1) Fungsi kenegaraan dijalankan oleh lembaga yang bersangkutan sesuai dengan ketetapan sebuah undang-undang dasar.

2) Undang-undang dasar menjamin hak asasi manusia yang paling penting. Karena tanpa jaminan tersebut, hukum akan menjadi sarana penindasan.

\footnotetext{
15 Ibid.

${ }^{16}$ Ali Muchtar, Pembuktian Indonesia sebagai Negara Hukum, Jakarta: Intan Press, 2010, hal. 3.
} 
PERAN PROFESI NOTARIS DALAM MENJAGA KEWIBAWAAN NEGARA HUKUM INDONESIA (Mirin Primudyastutie, Anang Sulistyono)

Jaminan hak asasi manusia memastikan bahwa pemerintah tidak dapat menyalahgunakan hukum untuk tindakan yang tidak adil atau tercela

3) Badan-badan negara menjalankan kekuasaan masing-masing selalu dan hanya taat pada dasar hukum yang berlaku.

4) Terhadap tindakan badan negara, masyarakat dapat mengadu ke pengadilan dan putusan pengadilan dilaksanakan oleh badan negara.

5) Badan kehakiman bebas dan tidak memihak. ${ }^{17}$

Negara hukum "rule of law" untuk Republik Indonesia antara lain harus mengacu pada Pembukaan UUD 1945 dan Pancasila yang menyebutkan bahwa negara melindungi segenap bangsa Indonesia dan seluruh tumpah darah Indonesia dan untuk memajukan kesejahteraan umum, mencerdaskan kehidupan bangsa, dan ikut melaksanakan ketertiban dunia yang berdasarkan kemerdekaan perdamaian abadi dan keadilan sosial. Negara hukum Republik Indonesia harus menganut asas dan konsep Pancasila yang terkandung dalam Pembukaan Undang-Undang Dasar 1945. (1) asas ketuhanan (mengamanatkan bahwa tidak boleh ada produk hukum nasional yang anti agama, anti ajaran agama), (2) asas kemanusiaan (mengamanatkan bahwa hukum nasional harus menjamin, melindungi hak asasi manusia), (3) asas kesatuan dan persatuan (mengamanatkan bahwa hukum Indonesia harus merupakan hukum nasional yang berlaku bagi ${ }^{17}$ Ibid, hal. 4-5. 
seluruh bangsa Indonesia, berfungsi sebagai pemersatu bangsa), (4) asas demokrasi (mengamanatkan bahwa kekuasaan harus tunduk pada hukum yang adil, demokratis), (5) asas keadilan sosial (mengamanatkan bahwa semua warga negara mempunyai hak yang sama dan bahwa semua orang sama di hadapan hukum). ${ }^{18}$

Sudah disebut sebelumnya, bahwa dasar pijakan negara Indonesia adalah negara hukum tertuang pada Pasal 1 ayat 3 UUD 1945, yang menyebutkan bahwa "Negara Indonesia adalah Negara Hukum". Dimasukkannya ketentuan ini ke dalam bagian pasal UUD 1945 menunjukkan semakin kuatnya dasar hukum serta menjadi amanat negara, bahwa negara Indonesia adalah dan harus merupakan negara hukum. Sebelumnya, landasan negara hukum Indonesia ditemukan dalam bagian Penjelasan Umum UUD 1945 tentang Sistem Pemerintahan Negara, yaitu sebagai berikut.

1) Indonesia adalah negara yang berdasar atas hukum (rechsstaat). Negara Indonesia berdasar atas Hukum (rechsstaat), tidak berdasar atas kekuasaan belaka (machtsstaat).

${ }^{18}$ Mochtar Kusumaatmadja, Pemantapan Cita Hukum dan Asas-Asas Hukum Nasional di Masa Kini dan Masa yang Akan Datang, Padjadjaran, Bandung: Alumni, 1995, hlm. 8 . 
PERAN PROFESI NOTARIS DALAM MENJAGA KEWIBAWAAN NEGARA HUKUM INDONESIA (Mirin Primudyastutie, Anang Sulistyono)

2) Sistem Konstitusional. Pemerintah berdasar atas sistem konstitusi (hukum dasar), tidak bersifat absolutisme (kekuasaan yang tidak terbatas). ${ }^{19}$

Berdasarkan perumusan di atas, negara Indonesia memakai sistem rechsstaat yang kemungkinan dipengaruhi oleh konsep hukum Belanda yang termasuk dalam wilayah Eropa Kontinental. Konsepsi negara hukum Indonesia dapat dimasukkan negara hukum materiil, yang dapat dilihat pada Pembukaan UUD 1945 Alenia IV. Dasar lain yang dapat dijadikan landasan bahwa negara Indonesia adalah negara hukum yakni pada Bab XIV tentang Perekonomian Nagara dan Kesejahteraan Sosial Pasal 33 dan 34 UUD 1945, yang menegaskan bahwa negara turut aktif dan bertanggung jawab atas perekonomian negara dan kesejahteraan rakyat.

Negara Hukum Indonesia menurut UUD 1945 mengandung prinsipprinsip sebagai berikut.

1) Norma hukumnya bersumber pada Pancasila sebagai hukum dasar nasional;

2) Sistem yang digunakan adalah Sistem Konstitusi;

3) Kedaulatan rakyat atau Prinsip Demokrasi;

4) Prinsip kesamaan kedudukan dalam hukum dan pemerintahan (Pasal 27 (1) UUD 1945);

19 http://prince-mienu.blogspot.com/2010/01/negara-hukum.html, akses 2 Juni 
5) Adanya organ pembentuk undang-undang (Presiden dan DPR);

6) Sistem pemerintahannya adalah Presidensiil;

7) Kekuasaan kehakiman yang bebas dari kekuasaan lain (eksekutif);

8) Hukum bertujuan untuk melindungi segenap bangsa Indonesia dan seluruh tumpah darah Indonesia, memajukan kesejahteraan umum, mencerdaskan kehidupan bangsa, dan ikut melaksanakan ketertiban dunia yang berdasarkan kemerdekaan, perdamaian abadi dan keadilan sosial; dan

9) Adanya jaminan akan hak asasi dan kewajiban dasar manusia (Pasal 28 A-J UUD 1945). ${ }^{20}$

Norma yuridis (peraturan perundang-undangan) merupakan norma yang secara das sollen sebagai produk lembaga yang berwenang (legislatif), namun akan dinilai kualitasnya ketika sudah masuk dalam ranah das sein (kenyataan atau praktik). ${ }^{21}$ Dari konstitusi hingga aturan dibawahnya, adalah cermin kepentingan asasi masyarakat. Setiap norma yuridis ini terlahir atau terbentuk adalah berkat latar sosial kebangsaan sebagai realitas empiriknya. Produk legislatif merupakan wujud pengakomodasian berbagai bentuk kepentingan riil di masyarakat, yang demikian ini mencerminkan bagian dari konstruksi negara hukum. Disinilah tuntutan menjaga kewibawaan negara hukum menjadi kewajiban utama dan 3istimewa profesi notaris.

Peran menjaga martabat negara hukum yang harus dilaksanakan oleh notaris itu menunjukkan, bahwa notaris memegang peran penting dalam dunia penegakan hukum. Peran penting yang dijalankan notaris ini diikat oleh peraturan perundang-undangan untuk menjalankan norma-norma hukum yang berkaitan diantaranya dengan tugas, kewajiban, kewenangan, larangan, dan lainnya, sehingga diantara peran ini, notaris dituntut untuk mempertanggungjawabkannya, khususnya dalam kaitannya dengan penegakan hukum.

\footnotetext{
${ }^{20}$ Ibid.

${ }^{21}$ Herlambang, Hukum Untuk Rakyat Indonesia, Jakarta: Pustaka Insani2012, hlm. 11 .
} 


\section{KESIMPULAN}

Peran penting atau mendasar yang dijalankan notaris ini diikat oleh peraturan perundang-undangan untuk menjalankan norma-norma hukum yang berkaitan diantaranya dengan tugas, kewajiban, kewenangan, larangan, dan lainnya, sehingga diantara peran ini, notaris dituntut untuk mempertanggungjawabkannya, khususnya dalam kaitannya dengan penegakan hukum.

Peran menjalankan norma-norma yuridis dalam hal tugas, kewajiban, kewenangan, larangan, dan lain sebagainya adalah menentukan terhadap bekerjanya hukum, sehingga yang dilakukannya ini mengandung konsekuensi yuridis, yakni kewibawaan negara hukum. Ada hak-hak masyarakat dan martabat negara yang ikut dirugikan ketika norma hukum tidak dijalankan sebagaimana mestinya. Kalau sudah begini, maka notaris berarti terlibat dalam perilaku atau perbuatan yang dilarang oleh peraturan perundang-undangan, atau terlibat dalam perbatan yang berlawanan dengan norma hukum. Norma yuridis merupakan norma yang mengatur apa yang harus dilakukan dan apa yang harus dihindari oleh notaris. Norma yuridis yang menjadi pijakan utama bagi notaris untuk menjalankan kewajibankewajiban atau kewenangan-kewenangannya.

\section{DAFTAR PUSTAKA}

\section{Buku}

Adjie, Habib, 2009. Meneropong Khazanah Notaris \& PPAT Indonesia (kumpulan tulisan tentang Notaris dan PPAT), Bandung: Citra ADitya Bakti

CST. Kansil, 2000, Pengantar Hukum dan Tata Hukum Indonesia, Jakarta: Djambatan

DPD-Unibraw, 2009, Konstruksi Perwakilan Daerah Dalam Sistem Ketatanegaraan Indonesia, Kerjasama DPD RI dan Universitas Brawijaya, Malang: Pusat Pengkajian Konstitusi Fakultas Hukum Universitas Brawijaya.

Ensiklopedi Nasional Indonesia, 2004, Jakarta: Delta Pamungkas.

Hamdi, Al-Hilal, 2017, Menjelajah Dunia Hukum, Jakarta: LPP-Mpres.

Herlambang, 2012, Hukum Untuk Rakyat Indonesia, Jakarta: Pustaka Insani.

Kusumaatmadja, Mochtar, 1995, Pemantapan Cita Hukum dan Asas-Asas Hukum Nasional di Masa Kini dan Masa yang Akan Datang, Padjadjaran, Bandung: Alumni

L.J. Van Apeldoorn, 1986, Pengantar Ilmu Hukum, Jakarta: Djambatan. 
Muchtar, Ali, 2010, Pembuktian Indonesia sebagai Negara Hukum, Jakarta: Intan Press.

Nusyirwan, 2000. Membedah Profesi Notaris, Bandung: Universitas Padjadjaran.

Tobing, G.H.S. Lumban, 1980, Peraturan Jabatan Notaris (Notaris Reglement), Jakarta: Erlangga.

Erlangga

Soekanto, Soerjono, 1986, Pengantar Penelitian Hukum, Jakarta: Sinar Grafika.

\& Sri Mamudji, 2003, Penelitian Hukum Normatf, Jakarta: Rajagrafindo Persada.

\section{Internet}

http://prince-mienu.blogspot.com/2010/01/negara-hukum.html, akses 2 Juni 2020. 